ROCZNIKI HUMANISTYCZNE

Tom LXVIII, zeszyt 2 - 2020

DOI: http://dx.doi.org/10.18290/rh20682-9

WITOLD JARNO

\title{
ZACIĄG DO ARMII OCHOTNICZEJ W OKRĘGU GENERALNYM WOJSKA POLSKIEGO NR IV ŁÓDŹ LATEM 1920 ROKU
}

Tematem artykułu jest zaciąg ochotniczy do polskiej armii latem $1920 \mathrm{r}$. prowadzony przez Okręgowy Inspektorat Armii Ochotniczej w Lodzi, jak również jego współpraca $\mathrm{z}$ organizacjami społecznymi $\mathrm{w}$ zakresie prowadzenia agitacji i werbunku oraz nadzorowania prac związanych $\mathrm{z}$ tworzeniem oddziałów ochotniczych na obszarze całego OGŁ ${ }^{1}$.

Formowanie tych oddziałów zostało wymuszone pogarszającą się sytuacją armii polskiej, toczącej boje z Armią Czerwoną, która zaczęła zagrażać niedawno odzyskanej niepodległości państwa polskiego. Od czerwca $1920 \mathrm{r}$. WP cofało się pod naporem wojsk bolszewickich, które szybko zbliżały się do polskiej stolicy. W tych ciężkich dla Polski dniach utworzono 23 czerwca nowy gabinet Władysława Grabskiego, 1 lipca zaś sejm uchwalił ustawę o powołaniu Rady Obrony Państwa, na której czele stanął Józef Piłsudski. Jednocześni podjęto działania zmierzające do powiększenia szeregów walczącej armii poprzez stworzenie Armii Ochotniczej. Jej organizowaniem zajął się - powstały na mocy rozkazu z 7 lipca - Generalny Inspektorat Armii Ochotniczej (na jego czele stanął gen. broni Józef Haller), zajmujący się organizowaniem i koordynowaniem akcji zaciągu ochotniczego, opracowywaniem wniosków w sprawach organizacji i wyszkolenia oddziałów ochotniczych oraz wydawaniem w tym zakresie rozkazów dowództwom Okręgów

Prof. nadzw. dr hab. WITOLD JARNO - Uniwersytet Łódzki, Wydział Filozoficzno-Historyczny, Katedra Historii Polski i Świata po 1945 r.; adres do korespondencji — e-mail: wjarnolodz@op.pl; ORCID: https://orcid.org/0000-0002-5845-6057.

${ }^{1} \mathrm{~W}$ pracy użyto następujących skrótów: AP - Archiwum Państwowe, CAW WBH - Centralne Archiwum Wojskowe Wojskowego Biura Historycznego, MSWojsk. - Ministerstwo Spraw Wojskowych, NDWP - Naczelne Dowództwo Wojska Polskiego, OG - Okręg Generalny, OGŁ - Okręg Generalny nr IV Łódź, pac - pułk artylerii ciężkiej, pap - pułk artylerii polowej, PCK - Polski Czerwony Krzyż, pp - pułk piechoty, pSK - pułk Strzelców Kaniowskich i WP - Wojsko Polskie. 
Generalnych, będących wojskowymi władzami terytorialnymi szczebla okręgowego. Przy tych ostatnich utworzono Okręgowe Inspektoraty Armii Ochotniczej, które w zakresie prowadzenia akcji zaciągowej i organizowania oddziałów ochotniczych podlegały bezpośrednio Generalnemu Inspektorowi Armii Ochotniczej poprzez dowódców właściwych Okręgów Generalnych² ${ }^{2}$.

Do kierowania akcją zaciągu ochotniczego na obszarze OGŁ - na mocy rozkazu Generalnego Inspektoratu Armii Ochotniczej z 8 lipca - utworzono siedem dni później Okręgowy Inspektorat Armii Ochotniczej w Łodzi przy Dowództwie OGŁ. Na jego czele stanął płk Michał Zienkiewicz, powołany na to stanowisko rozkazem z 14 lipca. Był to doświadczony 52-letni oficer, wywodzący się z armii rosyjskiej. Ukończył m.in. Korpus Kadetów w Petersburgu i Szkołę Junkierską w Wilnie. W armii rosyjskiej służył do grudnia 1917 r., a potem wstąpił do II Korpusu Polskiego w Rosji, po jego zaś rozbrojeniu powrócił do Polski i zgłosił się w lutym 1919 r. do polskiej armii. Początkowo dowodził 25 pp, w lipcu 1920 r. zaś został - jak wcześniej podano - Okręgowym Inspektorem Armii Ochotniczej przy Dowództwie OGE $^{3}$. Kierował nie tylko całokształtem akcji agitacyjno-werbunkowej do formacji ochotniczych prowadzonej na obszarze okręgu, ale także sprawował kontrolę nad procesem formowania oddziałów ochotniczych. Inspektorat zajmował się także zbieraniem funduszy na formowanie Armii Ochotniczej, organizowaniem pomocy materialnej dla rodzin ochotników, utrzymywaniem ścisłych kontaktów z lokalnymi stowarzyszeniami i organizacjami społecznymi wspierającymi zaciąg ochotniczy oraz nadzorował prowadzenie ewidencji ochotników. Siedzibą Inspektoratu był początkowo pałac przy al. Tadeusza Kościuszki 4 w Łodzi, w którym w latach 1918-1921 mieściło się Dowództwo OGŁ, następnie 16 sierpnia 1920 r. przeniesiono go do oficyny w budynku przy ul. Rozwadowskiej 1. Etatowa obsada Inspektoratu była niewielka, gdyż tworzyło ją zaledwie dwóch oficerów (jednym z nich był inspektor, drugim zaś oficer o nieustalonych personaliach), trzech szeregowych oraz jedna maszynistka - z czasem do pomocy przydzielono czasowo do Inspektoratu kilku innych oficerów ${ }^{4}$.

\footnotetext{
${ }^{2}$ CAW WBH, Dziennik Rozkazów Dowództwa OGŁ, Rozkaz nr 90 z 24 VII 1920 r.; Obrona państwa w 1920 roku. Księga sprawozdawczo-pamiatkowa Generalnego Inspektoratu Armii Ochotniczej i Obywatelskich Komitetów Obrony Państwa, red. W. Ścibor-Rylski, Warszawa 1923, s. 3, 6 i 72-73; M. WrzoseK, Wojny o granice Polski Odrodzonej 1918-1921, Warszawa 1992, s. 122.

${ }^{3}$ CAW WBH, Michał Zienkiewicz, ap. I.480.505, Kwestionariusz osobowy z 1925 r.

${ }^{4}$ CAW WBH, Okręg Korpusu nr IV Łódź, sygn. I.371.4.16, Sprawozdanie z działalności Okręgowego Inspektoratu Armii Ochotniczej w Łodzi z 21 X 1921 r.; Dziennik Rozkazów Do-
} 
Okręgowy Inspektorat Armii Ochotniczej przy Dowództwie OGŁ nadzorował również proces tworzenia straży obywatelskich, których członkowie pełnili służbę wartowniczą, co pozwalało na to, by część żołnierzy zajmujących się dotąd pilnowaniem łódzkich obiektów wojskowych wysłać na front, gdzie latem 1920 r. liczył się doprawdy każdy karabin. Inspektorat utrzymywał także ścisły kontakt z powstałymi we wszystkich powiatach na obszarze OGŁ Obywatelskimi Komitetami Obrony Państwa, które również prowadziły działalność propagandową na rzecz Armii Ochotniczej, zbierały dary na rzecz wojska w naturze i gotówce, dostarczały żywności żołnierzom przebywającym w szpitalach oraz organizowały na większości stacji kolejowych punkty żywnościowe lub gospody żołnierskie, w których sprzedawano żołnierzom żywność za minimalną opłatą. Z uwagi jednak na nieliczną obsadę Okręgowy Inspektorat Armii Ochotniczej mógł w praktyce jedynie kierować całością akcji zaciągu ochotniczego, faktyczną zaś działalność propagandową i agitacyjną ukierunkowaną na zachęcenie społeczeństwa do wstępowania w szeregi oddziałów ochotniczych prowadził - z ramienia Okręgowego Inspektora oraz dowódcy OGŁ - Wydział II Informacyjny sztabu Dowództwa OGŁ. Na jego czele stał wówczas kpt. Stefan Cieślak, któremu podlegało siedem referatów: Defensywny, Informacyjny, Prasowy, Propagandy, Dozoru Korespondencji, Jeńców i Internowanych oraz Stowarzyszeń WojskowoWychowawczych. Ich personel aktywnie zaangażował się w rozpoczętą w połowie lipca 1920 r. akcję propagandową na rzecz Armii Ochotniczej, prowadzoną głównie za pomocą spotkań z mieszkańcami, kolportowania wydawanych broszur agitacyjnych oraz publikowania ogłoszeń prasowych, odezw i apeli w prasie lokalnej ${ }^{5}$.

Od połowy lipca 1920 r. gazety łódzkie niemal codziennie zaczęły informować o ofiarności społeczeństwa na rzecz wojska oraz agitowały ludność do wstępowania w szeregi Armii Ochotniczej. Na przykład 16 lipca na łamach „Rozwoju” zawarto informację o mianowaniu przez gen. broni J. Hallera pełnomocnika Obywatelskiego Komitetu Wykonawczego Armii Ochotniczej na Województwo Łódzkiego, którym został wojewoda łódzki Antoni

wództwa OGŁ, Rozkaz tajny oficerski nr 56 z 24 VII 1920 r.; Obrona państwa w 1920, s. 107; K. CZernielewski, W. JARno, Garnizon tódzki Wojska Polskiego 1918-1939, Toruń 2008, s. 166; M. SZCZEPKOWSKI, Zaciąg ochotniczy i pobór do wojska na terenie Okręgu Generalnego Łódź w latach 1918-1921, „Rocznik Łódzki” 23 (26 ) (1978), s. 347-348.

${ }^{5}$ W. JARno, Okręg Korpusu Wojska Polskiego nr IV Łódź 1918-1939, Łódź 2001, s. 32-33; TENŻE, Samodzielny Referat Informacyjny Dowództwa Okręgu Korpusu nr IV Łódź w latach 191801939, w: Wywiad i kontrwywiad wojskowy II RP. Z dziatalności Oddzialu II SG WP, t. VIII, red. T. Dubicki, Łomianki 2017, s. 76-77. 
Kamieński, oraz o powołaniu płk. M. Zienkiewicza na stanowisko Okręgowego Inspektora Armii Ochotniczej przy Dowództwie OGŁ. W tyma samym numerze opublikowano również apel o wydźwięku propagandowym:

Akcja werbunkowa do Armii Ochotniczej rozpoczęta. Związki i Stowarzyszenia połączyły się celem wspólnej pracy. Uczniowie tutejszych szkół zaciągnęli się wszyscy. Wśród młodzieży zapał. Kobiety energicznie pracują w swoim zakresie. Zgłaszają się do służby wojskowej czternastoletnie dzieci, prosząc z płaczem o wysłanie na front. Pojawił się przed Komisją Zaciągową starzec 73-letni. Wszystkie warstwy społeczne rywalizują ze sobą w ofiarności ${ }^{6}$.

Wiadomości zawarte $\mathrm{w}$ powyższym cytowanym tekście są dobitnym przykładem postaw patriotycznych mieszkańców Łodzi i choć w rzeczywistości zaciąg do Armii Ochotniczej był znacznie mniejszy, niżby wynikało to z informacji prasowych, to niewątpliwie tego typu komunikaty wpływały na zwiększanie zaciągu ochotniczego do wojska.

Według założeń władz wojskowych celem obrony zagrożonej niepodległości kraju do Armii Ochotniczej mogły się zgłaszać osoby w wieku od 17 do 42 lat, gdy chodzi o szeregowych, oraz do 50 lat w odniesieniu do oficerów, które z różnych przyczyn nie podlegały obowiązkowi służby wojskowej. Dopuszczano więc możliwość przyjmowania tzw. małoletnich ochotników (czyli osób w wieku od 17 do 19 lat), lecz wymagano od nich pisemnej zgody rodziców bądź opiekunów. Z chwilą złożenia deklaracji każdy ochotnik był uważany za żołnierza armii czynnej i przysługiwały mu wszystkie prawa, takie jak żołnierzom z poboru. Wstępując do wojska, ochotnicy podpisywali deklarację, w której zobowiązywali się do służby wojskowej do czasu zakończenia działań wojennych, dzięki czemu otrzymywali od razu wszystkie uprawnienia przysługujące żołnierzom armii regularnej. Władze wojskowe zdecydowały też, by w szeregi tworzonej Armii Ochotniczej przyjmować jako ochotników również mężczyzn o słabszej kondycji zdrowotnej, lecz nadających się do służby wartowniczej i kancelaryjnej. Zachętą do zgłaszania się do punktów werbunkowych było przyznanie rodzinom ochotników zasiłków na zasadach ogólnych, tzn. w tej samej wysokości co rodzinom żołnierzy pełniących służbę z poboru. Ponadto za przyniesione ze sobą elementy umundurowania i wyposażenia ochotnicy otrzymywali ekwiwalent w wysokości rzeczywistej wartości rynkowej tych przedmiotów ${ }^{7}$.

\footnotetext{
6 „Echo” 1920, nr 183, s. 3.

${ }^{7}$ Obrona państwa w 1920, s. 37-38.
} 
Werbunkiem ochotników miały zajmować się wojskowe komisje zaciągowe tworzone przy powiatowych komendach uzupełnień oraz przy różnych instytucjach i organizacjach społecznych. Ponieważ w lipcu 1920 r. istniejące powiatowe komendy uzupełnień były i tak już nadmiernie obciążone poborem przymusowym, toteż władze wojskowe zgodziły się, by ochotnicy zgłaszali się również bezpośrednio do właściwych oddziałów zapasowych. W odniesieniu do piechoty określono, że ochotnicy mieszkający na obszarze danej powiatowej komendy uzupełnień (administrowała terenem jednego lub kilku powiatów) mieli być kierowani do dyslokowanego na jej obszarze batalionu zapasowego piechoty, ochotników zaś z obszaru całego okręgu chcących służyć w ochotniczych oddziałach konnych miano wysyłać do wyznaczonego - po jednym w każdym okręgu generalnym - szwadronu zapasowego ${ }^{8}$.

Na obszarze OGŁ przyjmowaniem ochotników zajmowało się latem $1920 \mathrm{r}$. 21 oddziałów zapasowych, z czego 11 stacjonowało w Łodzi: Batalion Zapasowy 28 Pułku Strzelców Kaniowskich, Batalion Zapasowy 31 Pułku Strzelców Kaniowskich, Bateria Zapasowa 10 Pułku Artylerii Polowej, Kompania Zapasowa 1 Pułku Czołgów, Kompania Zapasowa 4 Batalionu Telegraficznego, Kompania Zapasowa 4 Batalionu Saperów, Kolumna Zapasowa 4 Dywizjonu Samochodowego, Szwadron Zapasowy 4 Dywizjonu Taborowego, Batalion Zapasowy Wojsk Kolejowych nr 3, Batalion Zapasowy IV Batalionu Wojsk Wartowniczych i Etapowych oraz Szwadron Zapasowy 4 Dywizjonu Żandarmerii. Z kolei poza Łodzią kwaterowały następujące oddziały zapasowe: Batalion Zapasowy 10 Pułku Piechoty w Łowiczu, Batalion Zapasowy 14 Pułku Piechoty we Włocławku, Batalion Zapasowy 18 Pułku Piechoty w Koninie, Batalion Zapasowy 29 pSK w Kaliszu, Batalion Zapasowy 30 Pułku Strzelców Kaniowskich w Tomaszowie Mazowieckim oraz Batalion Zapasowy 37 Pułku Piechty w Kutnie, Szwadron Zapasowy 3 Pułku Ułanów w Kaliszu, Bateria Zapasowa 4 Pułku Artylerii Polowej we Włocławku, Bateria Zapasowa 4 Pułku Artylerii Ciężkiej w Kaliszu i Bateria Zapasowa 10 Pułku Artylerii Ciężkiej w Skierniewicach ${ }^{9}$. Komisje zaciągowe przy oddziałach zapasowych składały się z sześciu osób: dowódcy batalionu (względnie szwadronu, dywizjonu lub kompanii) zapasowego lub jego zastępcy, lekarza, oficera właściwej terytorialnie komendy uzupełnień, przedstawiciela starostwa oraz dwóch przedstawicieli miejscowego społe-

\footnotetext{
${ }^{8}$ Tamże, s. 58-59.

${ }^{9}$ We Włocławsku stacjonował jeszcze Szwadron Zapasowy 2 Pułku Szwoleżerów, lecz ochotników do służby w kawalerii nie kierowano do niego, a do Szwadronu Zapasowego 3 Pułku Ułanów w Kaliszu.
} 
czeństwa. Ochotników z kategorią „A” niezwłocznie kierowano do jednostek zapasowych, gdzie formowano $\mathrm{z}$ nich oddziały ochotnicze, ochotników zaś z kategoriami „B” i „C” - do Batalionu Zapasowego IV Batalionu Wojsk Wartowniczych i Etapowych w Lodzi ${ }^{10}$.

$\mathrm{Z}$ uwagi na potrzeby wojenne uproszczono do niezbędnego minimum proces werbunku ochotników, przydzielając większość ochotników zdolnych do służby frontowej do oddziałów piechoty. Do innych rodzajów broni warunki przydziału były nieco zaostrzone, gdyż do kawalerii (zwanej ówcześnie jazdą) przyjmowano tylko tych ochotników, którzy służyli już wcześniej w jednostkach kawalerii lub przybyli z własnym koniem, zaś do oddziałów artylerii i wojsk technicznych - tylko ochotników służących wcześniej w jednostkach broni technicznych lub posiadających odpowiednie kwalifikacje fachowe. $Z$ przyjętych ochotników miano niezwłocznie formować oddziały ochotnicze: w piechocie planowano utworzyć ochotnicze kompanie, bataliony i pułki, w kawalerii zaś szwadrony i ewentualnie pułki. Natomiast $\mathrm{w}$ artylerii i innych broniach technicznych nie przewidywano tworzenia odrębnych oddziałów ochotniczych, toteż ochotników miano kierować do jednostek zapasowych tych rodzajów broni, gdzie po przeszkoleniu miano ich wysyłać jako uzupełnienia do własnych jednostek walczących na froncie. Niebawem jednak MSWojsk. wyraziło zgodę na formowanie baterii, a nawet ochotniczych pułków artylerii, takie jednak nie powstały w OGŁ ${ }^{11}$.

Kadrę oficerską organizowanych oddziałów tworzyli oficerowie przydzieleni z armii stałej oraz mianowani spośród ochotników (posiadających odpowiednie wykształcenie) po ukończeniu krótkich kursów oficerskich. Pułki ochotnicze miały nosić numer pułku, przy którego oddziale zapasowym zostały sformowane, podwyższony o dwieście - na przykład pułk ochotniczy organizowany przez Batalion Zapasowy 28 pSK w Łodzi miał nosić numer 228. Celem wsparcia procesu formowania formacji ochotniczych oddziały zapasowe miały wydzielić ze swego składu niezbędne kadry oficerskie i podoficerskie. Ponieważ kadr tych było zbyt mało, toteż w Łodzi utworzono pod koniec lipca Ochotniczą Szkołę Podoficerską oraz zorganizowano przyspieszone kursy dla oficerów-ochotników. Tworzone oddziały ochotnicze miały podlegać gospodarczo i materiałowo oddziałom zapasowym, przy których były formowane, co ułatwiło ich bieżące zaopatrywanie w niezbędne wyposażenie. Zgodnie ze wstępnymi założeniami na obszarze OGŁ plano-

\footnotetext{
${ }^{10}$ CAW WBH, Dziennik Rozkazów Dowództwa OGŁ, Rozkaz tajny oficerski nr 47 z 23 VI $1920 \mathrm{r}$.

${ }^{11}$ Obrona państwa w 1920, s. 37-38.
} 
wano sformować osiem ochotniczych pułków piechoty, mających numer swego własnego pułku podwyższony o dwieście, czyli ochotnicze 210, 214, 218, 228, 229, 230, 231 i 237 pp, w tym 228 i 231 pp w Łodzi. Natomiast w odniesieniu do jazdy - w przypadku OGŁ - wszystkich ochotników miano kierować do Szwadronu Zapasowego 3 Pułku Ułanów w Kaliszu, ochotników zaś zgłaszających się do jednostek artylerii lub innych wojsk technicznych - do najbliższej formacji zapasowej artylerii lub właściwego rodzaju wojsk technicznych ${ }^{12}$.

Dla zachęcenia ludności do wstępowania do Armii Ochotniczej Generalny Inspektor Armii Ochotniczej gen. broni J. Haller wydał 15 lipca 1920 r. specjalną odezwę do społeczeństwa, w której czytamy m.in.:

Dziś zagrożona wolność nasza. Na progu będziemy bronić wejścia. Żołnierz czynnej Armji Rzeczypospolitej bohatersko walczy, za cenę krwi swej przelanej, dając Ojczyźnie możność organizacji państwowej, a obywatelom bezpieczeństwo i spokój w pracy. Lecz, gdy bolszewicka Rosja wzmogła swe siły militarne, w Polsce stale też sama szczupła Armja dotychczas odpiera wszystkie ataki. Przyszła zatem teraz kolej na Was, którzy jako ochotnicy, wspomóc pragniecie Armję i wspólnie z nią walczyć. Powstańcie dla obrony Ziem Polskich, dla obrony życia i mienia obywateli, dla obrony wolności i najświętszych ideałów Polski przed zalewem barbarzyństwa i nieubłaganej zemsty nad naszą Ojczyzną ${ }^{13}$.

Również władze cywilne i wojskowe poszczególnych okręgów prowadziły w tym celu szeroką akcję propagandową, wydając liczne odezwy i apele, np. w jednym z nich - wydanym przez dowódcę OGŁ gen. ppor. Kajetana Olszewskiego - czytamy m.in.:

Ojczyzna w niebezpieczeństwie! Mrowie dziczy mongolskiej, czerwone hordy Budionnego dobijają się do wrót Rzeczypospolitej, niosąc zagładę i spustoszenie wsiom naszym, polom i niwom. Kto żyw - pod broń staje, by tarczą swej piersi bronić Wolności i Niepodległości, by męskim ramieniem odeprzeć najazd moskiewski od zagród naszych rodzinnych. [...] Obywatele ziemianie i włościanie! Wy wszyscy, którzy posiadacie konie, a często też broń i rynsztunek, najszczytniejszą i najpożyteczniejszą usługę oddacie Ojczyźnie, jeśli będziecie się zgłaszać, bądź pojedynczymi, bądź całymi oddziałami konnymi w najbliższych punktach werbunkowych. [...] Twórzcie liczne i niezwyciężone pułki i dywizje kawaleryjskie i spieszcie na granicę Rzeczypospolitej ${ }^{14}$.

\footnotetext{
${ }^{12}$ W. JARNO, Okręg Korpusu, s. 78.

${ }^{13}$ Obrona państwa w 1920, s. 18.

${ }^{14}$ AP Łódź, Zbiór druków i pism ulotnych, sygn. 575/394, dokument 44. Odezwa gen. ppor. Kajetana Olszewskiego z lipca 1920 r.
} 
Oprócz apeli i odezw, agitację prowadzono poprzez bezpośrednie spotkania z ludnością, którą to działalnością kierował Wydział II - Informacyjny Dowództwa OGŁ. Poprzez aktywną propagandę, prowadzoną zarówno przez władze wojskowe, jak i liczne organizacje społeczne, starano się zachęcić społeczeństwo do wstępowania w szeregi Armii Ochotniczej. W tym też celu zorganizowano 25 lipca w Łodzi obchody Dnia Armii Ochotniczej, rozpoczęte mszą polową na placu Dąbrowskiego z udziałem łódzkich władz wojskowych i samorządowych. Po nabożeństwie proboszcz garnizonu łódzkiego, ks. kapelan Stanisław Ostachowicz, wygłosił patriotyczne kazanie, a następnie kpt. Alfred Biłyk (komendant miasta) odczytał - wydany przez dowódcę OGŁ - rozkaz do żołnierzy-ochotników. Na zakończenie odbył się pochód mieszkańców z udziałem delegacji różnych organizacji i stowarzyszeń społecznych, który zakończył się na ul. Piotrkowskiej w rejonie Hotelu Grand. Tu miała miejsce defilada wojskowa przy dźwiękach patriotycznych marszy granych przez orkiestrę wojskową, czemu towarzyszył wielki entuzjazm zgromadzonych przy ulicy łodzian. Podobne spotkania agitacyjne z ludnością - choć oczywiście na mniejszą skalę - organizowano we wszystkich powiatach wchodzących w skład OGŁ. Uczestniczyli w nich - oprócz mówców oddelegowanych przez Wydział II sztabu dowództwa okręgu - także politycy i wytypowani oficerowie z ramienia Okręgowego Inspektoratu Armii Ochotniczej, np. w Łodzi - poseł Bolesław Fichna, w powiecie zaś kaliskim, kolskim i konińskim - płk Hipolit Nowicki ${ }^{15}$.

Inspektorat Okręgowy Armii Ochotniczej przy Dowództwie OGŁ prowadził również akcję zbierania środków finansowych na rzecz tworzonej Armii Ochotniczej. Ogółem zebrano na ten cel kwotę 141864 marek polskich oraz biżuterię o wartości około 1000 marek polskich - kwoty te zostały przekazane do kasy Komisji Funduszu Armii Ochotniczej przy Dowództwie Miasta Łodzi. Dużą wagę przykładano również do niesienia pomocy pieniężnej rodzinom ochotników, szczególnie ze środowisk robotniczych. Z powodu jednak niewystarczających środków finansowych na ten cel pomoc ta była realizowana jedynie $\mathrm{w}$ odniesieniu do rodzin najbardziej potrzebujących, po konsultacjach ze związkami zawodowymi i zasięgnięciu informacji o sytuacji materialnej konkretnej rodziny we właściwych komisariatach policji ${ }^{16}$.

${ }^{15}$ CAW WBH, Okręg Korpusu nr IV Łódź, sygn. I.371.4.16, Sprawozdanie z działalności Okręgowego Inspektoratu Armii Ochotniczej w Łodzi z 21 X 1921 r.; „Rozwój” 1920, nr 193, s. 3; „Głos Polski” 1920, nr 197, s. 3.

${ }^{16}$ CAW WBH, Okręg Korpusu nr IV Łódź, sygn. I.371.4.16, Sprawozdanie z działalności Okręgowego Inspektoratu Armii Ochotniczej w Łodzi z 21 X 1921 r. 
Kolejnym elementem działalności Inspektoratu było utrzymywanie stałych kontaktów ze wszystkimi organizacjami i stowarzyszeniami działającymi na obszarze OGŁ, w tym w szczególności z Obywatelskim Komitetem Obrony Państwa na Województwo Łódzkie powstałym 10 lipca. Na jego czele stał - jak wcześniej podano - Antoni Kamieński, wojewoda łódzki, który kilka dni później powołał Radę Komitetu Wojewódzkiego, złożoną m.in. z ks. prałata Wincentego Tymienieckiego, Tomasza Stożkowskiego, Kazimierza Rossmana, Leona Chwalbińskiego, Wiktora Groszkowskiego, Aleksego Rżewskiego, Kazimierza Sadoczyńskiego i Józefa Wolczyńskiego. Głównym zadaniem wspomnianej Rady było koordynowanie prac podległych jej powiatowych komitetów Obrony Państwa oraz udzielanie im pomocy w organizowaniu agitacji na rzecz Armii Ochotniczej. Ogółem na obszarze OGŁ utworzono 19 komitetów powiatowych i miejskich oraz niemal w każdej gminie komitety gminne. Na skutek poczynionych uzgodnień nie utworzono odrębnego Obywatelskiego Komitetu Obrony Państwa na Miasto Łódź, jego zadania zaś wypełniał Wojewódzki Komitet Obrony Państwa w Lodzi. Wszystkie komitety prowadziły kampanię propagandową na rzecz wstępowania w szeregi Armii Ochotniczej, organizując liczne wiece, na których wskazywano na konieczność współdziałania społeczeństwa z wojskiem. Ogółem w okresie od lipca do końca września 1920 r. na obszarze OGŁ odbyło się z inicjatywy wspomnianych komitetów 269 wieców, w każdym z nich zaś uczestniczyło średnio po około 2 tys. osób. Przy tej okazji rozlepiono 12 różnych plakatów propagandowych w łącznej liczbie niemal 43 tys. egzemplarzy oraz rozdano niemal 10 tys. pocztówek agitacyjnych. Choć wszystkie komitety obywatelskie miały własne Sekcje Agitacyjne i organizowały samodzielnie wiece i zebrania, to jednak pozostawały w ścisłym kontakcie z Referatem Propagandy Wydziału II sztabu Dowództwa OGŁ, który mając w swej dyspozycji kilkunastu przygotowanych mówców, oddelegowywał ich na wspomniane wiece. Komitety zajmowały się także dostarczaniem części ekwipunku i żywności oddziałom ochotniczym oraz żołnierzom przebywającym na froncie. Ponadto organizowały pomoc dla rodzin żołnierzy-ochotników, na stacjach kolejowych zaś tworzyły z własnej inicjatywy i finansowały punkty żywieniowe dla żołnierzy (tylko na stacji Łódź-Kaliska wydano niemal 85 tys. porcji). Dodatkowo zakładały i utrzymywały na własny koszt na obszarze OGŁ 6 niewielkich szpitali na potrzeby wojska (łącznie na 285 łóżek) - powstały one np. w Zduńskiej Woli (na 60 łóżek), Warcie (na 20 łóżek) czy Sieradzu (na 70 łóżek), jak również improwizowane 4 uzdrowiska dla żołnierzy, mające łącznie 180 miejsc. Obywatelskie komitety zorganizowały dla potrzeb ochotników warsztaty szew- 
skie i krawieckie, w których robotnicy bezpłatnie pracowali przy naprawie elementów umundurowania (np. koszule, kalesony, spodnie, buty itp.) noszonego przez ochotników ${ }^{17}$.

Tabela 1. Obywatelskie Komitety Obrony Państwa na obszarze OGŁ latem 1920 r.

\begin{tabular}{|c|c|c|}
\hline NAZWA POWIATOWYCH KOMITETÓW OBRoNy PańSTWA & DATA POWSTANIA & PEenOMOCNICY KOMITETÓW \\
\hline Obywatelski Komitet Obrony Państwa na Powiat Gostyniński & połowa lipca $1920 \mathrm{r}$. & Władysław Kowalewski \\
\hline Obywatelski Komitet Obrony Państwa na Powiat Nieszawski & 3 VIII 1920 r. & Władysław Wiśniewski \\
\hline Obywatelski Komitet Obrony Państwa na Powiat Kutnowski & połowa lipca $1920 \mathrm{r}$. & Antoni Troczewski \\
\hline Obywatelski Komitet Obrony Państwa na Powiat Łowicki & 22 VII $1920 \mathrm{r}$. & Stanisław Brzęczek \\
\hline Obywatelski Komitet Obrony Państwa na Powiat Rawski & $10 \mathrm{VII} 1920 \mathrm{r}$. & Edward Otto \\
\hline Obywatelski Komitet Obrony Państwa na Powiat Włocławski & $8 \mathrm{VII} 1920 \mathrm{r}$. & Aleksander Barcikowski \\
\hline Obywatelski Komitet Obrony Państwa na Powiat Skierniewicki & $10 \mathrm{VII} 1920 \mathrm{r}$. & Wacław Gajewski \\
\hline Obywatelski Komitet Obrony Państwa na Powiat Sochaczewski & połowa lipca $1920 \mathrm{r}$. & Władysław Karnkowski \\
\hline Obywatelski Komitet Obrony Państwa na Powiat Brzeziński & $17 \mathrm{VII} 1920 \mathrm{r}$. & Feliks Zdzitowiecki \\
\hline Obywatelski Komitet Obrony Państwa na Powiat Kaliski & 27 VII 1920 r. & NN \\
\hline Obywatelski Komitet Obrony Państwa na Powiat Kolski & $14 \mathrm{VII} 1920 \mathrm{r}$. & Władysław Klimaszewski \\
\hline Obywatelski Komitet Obrony Państwa na Powiat Koniński & 7 VII $1920 \mathrm{r}$ & Jan Augustowski \\
\hline Obywatelski Komitet Obrony Państwa na Powiat Łaski & $11 \mathrm{IX} 1920 \mathrm{r}$. & Stanisław Kobierzycki \\
\hline Obywatelski Komitet Obrony Państwa na Powiat Łęczycki & 9 VII 1920 r. & Stanisław Wehr \\
\hline Obywatelski Komitet Obrony Państwa na Powiat Łódzki & 17 VII $1920 \mathrm{r}$. & Wiesław Gerlicz \\
\hline Obywatelski Komitet Obrony Państwa na Powiat Sieradzki & 8 VII 1920 r. & Bronisław Szybowski \\
\hline Obywatelski Komitet Obrony Państwa na Powiat Słupecki & 16 VII $1920 \mathrm{r}$. & Edward Matuszewski \\
\hline Obywatelski Komitet Obrony Państwa na Miasto Tomaszów Mazowiecki & 7 VII $1920 \mathrm{r}$. & Stanisław Narewski \\
\hline Obywatelski Komitet Obrony Państwa na Powiat Turecki & 12 VII $1920 \mathrm{r}$. & Tomasz Glądała \\
\hline
\end{tabular}

Źródło: Obrona państwa w 1920, s. 251 nn.

Celem zacieśnienia współdziałania z lokalnymi społecznościami Okręgowy Inspektorat Armii Ochotniczej w Łodzi nawiązał bliską współpracę

${ }^{17}$ CAW WBH, Okręg Korpusu nr IV Łódź, sygn. I.371.4.16, Sprawozdanie z działalności Obywatelskiego Komitetu Rady Obrony Państwa na Województwo Łódzkie za czas od 10 lipca do 1 października 1920 r.; Obrona państwa w 1920, s. 304. 
z większością stowarzyszeń działających na obszarze OGŁ. Okręg Łódzki Związku Sokolstwa Polskiego zorganizował kilkanaście biur zaciągowych, zwerbowanych zaś ochotników - członków „gniazd sokolskich” - kierowano: w Łodzi - do Batalionu Zapasowego 28 pSK, przy którym miał się formować Batalion Ochotniczy złożony z członków „Sokoła”, ochotników w Pabianicach i Piotrkowie Trybunalskim - do ochotniczego 202 pp w Kielcach, zaś w Kaliszu - jako uzupełnienie do Brygady Syberyjskiej. Ogółem spośród członków „Sokoła” zwerbowano w OGŁ 356 osób w wieku od 17 do 35 lat, niezakwalifikowanych zaś skierowano do służby pomocniczej w wojsku oraz do Straży Obywatelskiej ${ }^{18}$.

Kolejną organizacją aktywnie wspierającą akcję zaciągu ochotniczego był Związek Harcerstwa Polskiego, na którego czele od 3 lipca 1920 r. stał gen. broni J. Haller. Pod wpływem informacji o pogarszającej się sytuacji na froncie Związek wydał 13 lipca rozkaz o mobilizacji wszystkich harcerzy: mający powyżej 17 lat mieli zasilić tworzone pułki ochotnicze, poniżej zaś 17 roku życia winni zgłosić się do pełnienia w wyznaczonych miejscach służby wartowniczej i łącznikowej oraz pomocy rannym. Odzew Chorągwi Łódzkiej na wspomniany rozkaz był stosunkowo duży, gdyż już w dniach 17-23 lipca wyjechało z Łodzi do stolicy łącznie około 450 harcerzy, których wcielono do ochotniczych 201, 205, 232 i 236 pp. Większość harcerzy z OGŁ została włączona w skład wyżej wymienionych pułków ochotniczych, jedynie w 7 i 8 kompanii II batalionu 201 pp stanowili oni zdecydowaną większość ( 8 kompania powstała wyłącznie na bazie harcerzy chorągwi łódzkiej, a 7 kompania - na bazie harcerzy chorągwi kaliskiej i sieradzkiej). Ponadto z drużyn żeńskich zgłosiło się 15 druhen powyżej 17 roku życia, które wyjechały do Warszawy, gdzie przydzielono je do kilku tzw. czołówek sanitarno-odżywczych ${ }^{19}$. Warto tu wspomnieć, że 8 lipca zwołano w Łodzi wielki wiec młodzieży szkolnej „[...] na którym uchwalono, że uczniowie dwóch najstarszych klas zgłaszają się ochotniczo do wojska. Ci, którzy uchylają się od służby ochotniczej, pozbawieni zostaną prawa wstępu na uczelnie. Podobne zobowiązanie podjęła młodzież robotnicza i rzemieślnicza zrzeszona w «Strzelcu», «Sokole» $\mathrm{i}$ innych organizacjach"20. Oprócz służby w jednostkach liniowych harcerze-ochotnicy prowadzili wśród ludności ak-

\footnotetext{
${ }^{18}$ CAW WBH, Okręg Korpusu nr IV Łódź, sygn. I.371.4.16, Sprawozdanie z działalności Okręgowego Inspektoratu Armii Ochotniczej w Łodzi z 21 X 1921 r.

${ }^{19}$ CAW WBH, Okręg Korpusu nr IV Łódź, sygn. I.371.4.16, Sprawozdanie z działalności Chorągwi Łódzkiej Związku Harcerstwa Polskie z akcji na rzecz Armii Ochotniczej z 15 X 1920 r.

${ }^{20}$ H. SKONIECZnY, Wkład „Dzieci Łódzkich” w „cud nad Wista”, „Dziennik Łódzki” 1990, nr 188 , s. 4.
} 
cje zbierania żywności dla żołnierzy walczących na froncie. Z czasem, w miarę przywożenia do Łodzi rannych harcerzy z Batalionu Harcerskiego, zrodziła się potrzeba zorganizowania dla nich odrębnego małego szpitala z inicjatywy Chorągwi Łódzkiej tzw. Szpitalik Harcerski na 13 łóżek powstał już 26 lipca w izbie VIII Drużyny Żeńskiej przy ul. Długiej 27. Po kil$\mathrm{ku}$ tygodniach został on przeniesiony do większego lokalu otrzymanego od Związku Kolejarzy przy ul. Kilińskiego 73 (teraz miał 25 łóżek), gdzie działał do 2 lutego 1921 r. Drugi szpitalik harcerski powstał w końcu lipca 1920 r. w Kaliszu, a w następnym miesiącu został przejęty przez PCK. Ponadto harcerze pełnili, w porozumieniu z władzami wojskowymi, służbę wartowniczą przy magazynach wojskowych ${ }^{21}$.

Ważną rolę w działaniach wspierających zaciąg ochotniczy odegrał Łódzki Oddział Okręgowy PCK (choć samym werbunkiem się nie zajmował), zwłaszcza w zakresie niesienia pomocy rannym i chorym żołnierzom. $\mathrm{W}$ tym celu zorganizował $\mathrm{w}$ Łodzi własny szpital oraz roztoczał opiekę nad kilkunastoma szpitalami wojskowymi w OGŁ (chodziło głównie o pielęgniarki i lekarzy oddelegowanych do nich z ramienia PCK). Oddział Łódzki PCK prowadził także tzw. Gospodę Żołnierską w Łodzi, wydającą dziennie średnio po 3 tys. obiadów, oraz zbierał pieniądze, żywność i ubrania dla żołnierzy, w czym szczególnie pomocna okazała się jedna z jego sekcji - Sekcja „Chrzestnych Matek”. Nie mniej aktywnie działała Liga Kobiet Polskich w Lodzi, zajmująca się działalnością propagandową i agitacyjną - prowadziła także własną tzw. Gospodę Żołnierską przy ul. Przejazd. W akcji werbunkowej pomagało także Koło Polek w Łodzi, której członkinie pracowały w biurach werbunkowych, wysyłały paczki żywnościowe dla żołnierzy na froncie, pomagały przy szyciu bielizny wojskowej oraz przy organizowaniu imprez kulturalnych i koncertów dla żołnierzy w łódzkim garnizonie. Dużą aktywnością wykazały się także polskie związki zawodowe, udostępniając swe lokale na potrzeby biur werbunkowych oraz organizując kwesty i akcje zbierania różnych rzeczy dla potrzeb żołnierzy. Wśród tych związków warto w tym kontekście wymienić Związek Polskiego Nauczycielstwa Szkół Powszechnych w Łodzi czy Związek Zawodowy Pracowników Tramwajowych Polski - Oddział w Łodzi. Nie można pominąć tu także Ochotniczej Straży

\footnotetext{
${ }^{21}$ W. Nekrasz, Harcerze $w$ bojach. Przyczynek do udziatu młodzieży polskiej $w$ walkach o niepodległość ojczyzny w latach 1914-1921, Warszawa 1930, cz. 2, s. 24, 144 i 247-248; J. SZCZEPAŃSKI, Harcerstwo polskie w wojnie polsko-bolszewickiej 1920 roku, „Harcerstwo” 1993, nr 7/8, s. 31-33; W. BŁAŻEJEWSKI, Z dziejów harcerstwa polskiego (1910-1939), Warszawa 1985, s. 150; E. AJNENKIEL, J. WARĘŻAK, Lódź w walce o niepodległość Polski, Łódź 1938, s. 15.
} 
Ogniowej, której wszystkie oddziały na obszarze OGŁ aktywnie wspierały działania związane z akcją werbunkową i służbę wartowniczą przy magazynach wojskowych ${ }^{22}$.

Agitację prowadziły również łódzkie struktury polskich partii politycznych, jak np. Narodowej Partii Robotniczej czy Polskiej Partii Socjalistycznej. Zarząd Łódzki pierwszej z nich już 11 lipca na specjalnym posiedzeniu zdecydował o rozpoczęciu akcji zachęcającej do wstępowania w szeregi Armii Ochotniczej oraz podjęciu energicznych działań zmierzających do podniesienia ducha walki w społeczeństwie. Kierownictwo nad akcją werbunkową prowadzoną przez łódzkie struktury Narodowej Partii Robotniczej objął poseł Bolesław Fichna, który koordynował zwoływanie zebrań dla członków partii, na których omawiano trudną sytuację na froncie i konieczność walki z wrogiem. W ciągu kilku dni zorganizowano w Łodzi cztery biura zaciągowe, w których przyjmowano ochotników z szeregów partii: przy ul. Piotrkowskiej 91, przy ul. Głównej 31, przy ul. Kątnej 2 i przy ul. Franciszkańskiej 53. Zgłosiło się w nich do Armii Ochotniczej łącznie około 500 osób, z czego 304 otrzymały kategorię „A” i zostały wcielone do oddziałów ochotniczych. Poza Łodzią działacze Narodowej Partii Robotniczej zorganizowali biura werbunkowe także w większości miast powiatowych na terenie województwa łódzkiego. Podobną postawę przyjęła Polska Partia Socjalistyczna, stojąca na stanowisku konieczności obrony ledwo co odzyskanej niepodległości. Jej lokalne struktury w województwie łódzkim także wzięły aktywny udział w werbunku ochotników, zbieraniu datków na rzecz Armii Ochotniczej oraz udzielaniu pomocy żołnierzom. Pełnomocnikiem wojskowym Centralnego Komitetu Wykonawczego tej partii na województwo łódzkie był Aleksy Rżewski. W samej Łodzi do Armii Ochotniczej zgłosiło się 190 członków wspomnianej partii - zaciąg prowadzono także w innych miastach województwa, lecz brak informacji nie pozwala podać choćby przybliżonej liczby jej członków, jacy się ochotniczo zgłosili²3

Pomimo zakrojonej na szeroką skalę akcji propagandowej napływ ochotników do punktów werbunkowych i komisji zaciągowych nie był równomierny, gdyż w pierwszym tygodniu zaciągu przyjęto w całym kraju do wojska ok. 30 tys. osób, lecz w kolejnych tygodniach ich liczba systematycznie

\footnotetext{
${ }^{22}$ CAW WBH, Okręg Korpusu nr IV Łódź, sygn. I.371.4.16, Sprawozdanie z działalności Okręgowego Oddziału Łódzkiego PCK z działań na rzecz Armii Ochotniczej z 15 X 1920 r. oraz Sprawozdanie Ligii Kobiet Polskich w Łodzi z działań na rzecz Armii Ochotniczej z 15 X 1920 r.

${ }^{23}$ CAW WBH, Okręg Korpusu nr IV Łódź, sygn. I.371.4.16, Pismo Łódzkiego Komitetu Okręgowego Polskiej Partii Socjalistycznej z 26 X 1920 r. oraz Sprawozdanie Zarządu Łódzkiego z akcji zaciągowej Narodowej Partii Robotniczej z października 1920 r.
} 
malała. Zasadniczy wpływ na to miała poprawiająca się sytuacja na froncie, dzięki czemu zaciąg ochotniczy stał się we wrześniu 1920 r. zbędny, co spowodowało, że zakończono go z końcem tego miesiąca. Ogółem szeregi armii polskiej w okresie od 10 lipca do 30 września zasiliło 105714 ochotników, co poważnie ją wzmocniło w najtrudniejszym dla kraju okresie wojny polsko-bolszewickiej. Spośród ochotników 13391 zgłosiło się na obszarze OGŁ, co stanowiło 12,6 \% wszystkich ochotników. Liczba ta nie oddaje w pełni wysiłku ludności ziemi łódzkiej, gdyż kilku tysięcy ludzi z różnych powodów (głównie zdrowotnych) do służby wojskowej nie wcielono ${ }^{24}$.

Tabela 2. Wyniki zaciągu do Armii Ochotniczej w 1920 r.

\begin{tabular}{|c|c|c|c|c|c|c|c|c|c|c|c|c|c|}
\hline \multirow{2}{*}{$\begin{array}{l}\text { OKRĘG GENE- } \\
\text { RALNY }\end{array}$} & \multicolumn{12}{|c|}{ ZESTAWIENIE TYGODNIOWE } & \multirow{2}{*}{$\frac{\text { OGótem }}{10 \mathrm{VII}-30 \mathrm{IX}}$} \\
\hline & $10-16 \mathrm{VII}$ & $17-23 \mathrm{VII}$ & $24-30 \mathrm{VII}$ & $\begin{array}{l}31 \mathrm{VII}- \\
6 \mathrm{VIII}\end{array}$ & $\begin{array}{l}7-13 \\
V I I I\end{array}$ & $14-20 \mathrm{VIII}$ & $\begin{array}{c}21-27 \\
V \| I I\end{array}$ & $\begin{array}{l}28 \mathrm{VIII} \\
-3 \mathrm{IX}\end{array}$ & $4-10 \mid X$ & $\begin{array}{l}11- \\
17 \mid X\end{array}$ & $\begin{array}{c}18- \\
24 I X\end{array}$ & $\begin{array}{c}25- \\
30 I X\end{array}$ & \\
\hline Warszawa & 9798 & 7183 & 2958 & 2821 & 1533 & 1659 & 937 & 566 & 321 & 195 & 109 & 47 & $\begin{array}{c}28527 \\
(26,9 \%)\end{array}$ \\
\hline Lwów & 2685 & 2465 & 1668 & 622 & 1329 & 646 & 739 & 421 & 209 & 187 & 96 & 80 & $\begin{array}{c}16977 \\
(16,1 \%)\end{array}$ \\
\hline tódź & 5613 & 3041 & 1246 & 1489 & 816 & 487 & 342 & 175 & 58 & 64 & 48 & 12 & $\begin{array}{c}13391 \\
(12,6 \%)\end{array}$ \\
\hline Poznań & 4129 & 2128 & 1327 & 1643 & 1365 & 877 & 461 & 201 & 32 & 100 & 34 & 16 & $\begin{array}{c}12253 \\
(11,5 \%)\end{array}$ \\
\hline Kraków & 3408 & 1852 & 1417 & 1856 & 891 & 8170 & 500 & 310 & 127 & 105 & 33 & 23 & $\begin{array}{c}11392 \\
(10,8 \%)\end{array}$ \\
\hline Kielce & 2619 & 2439 & 1412 & 1285 & 685 & 535 & 382 & 421 & 95 & 54 & 11 & 17 & $\begin{array}{c}9706 \\
(9,5 \%)\end{array}$ \\
\hline Pomorze & 271 & 663 & 1126 & 1946 & 1298 & 1255 & 749 & 682 & 389 & 13 & 35 & 22 & $\begin{array}{l}8449 \\
(7,9 \%)\end{array}$ \\
\hline Lublin & 1900 & 1591 & 787 & 313 & 93 & 164 & 77 & 27 & 35 & 21 & 6 & 5 & $\begin{array}{c}5019 \\
(4,7 \%)\end{array}$ \\
\hline Razem & 30423 & 21362 & 11941 & 11975 & 8410 & 6443 & 4187 & 2554 & 1266 & 739 & 372 & 222 & $\begin{array}{l}105714 \\
(100 \%)\end{array}$ \\
\hline
\end{tabular}

Źródło: Obrona państwa w 1920, tabela po s. 36.

Spośród ogółu przyjętych w całym kraju ochotników do wojska, aż 52 690 (czyli 49,8 \%) wcielono do oddziałów piechoty, 12495 (11,8 \%) - do

\footnotetext{
${ }^{24}$ Obrona państwa w 1920, s. 39.
} 
artylerii, $11285(10,7 \%$ ) - do wojsk wartowniczych, po 9456 (po 8,9 \%) do jazdy i wojsk technicznych, $6683(6,4 \%)$ - do innych formacji oraz 3 $659(3,5 \%)$ - do poszczególnych dowództw jako tzw. siły kancelaryjne. Trzeba tu dodać, iż zdecydowana większość ochotników, bo aż 102379 (czyli 96,9 \%) była katolikami. Pod względem ochotników przyjętych do wojska, OGŁ zajął trzecie miejsce, po OG Warszawa i OG Lwów, wyprzedził natomiast OG Poznań, OG Kraków, OG Kielce, OG Pomorze i OG Lublin. Jednakże wysiłek poszczególnych okręgów widać lepiej, jeśli porównamy liczbę ochotników w każdym z nich do liczby mieszkańców poszczególnych okręgach oraz do ilości osób podlegających obowiązkowi służby wojskowej. Okaże się wówczas, iż wysiłek OGŁ - choć niewątpliwie duży - nie był jednak tak wyraźny, gdyż liczba przyjętych ochotników na jego obszarze w stosunku do ogółu ludności tegoż okręgu stanowiła tylko 0,54 \%. Pod tym względem zajął on czwarte miejsce, po OG Warszawa, OG Pomorze i OG Poznań, wyprzedzając z kolei OG Kraków, OG Lwów, OG Kielce i OG Lublin, gdzie ów stosunek wyniósł zaledwie 0,26 \% (pamiętać jednak trzeba iż na obszarze tego ostatniego okręgu trwały działania wojenne). Znacznie gorzej wypadł OGŁ w porównaniu liczby zaciągniętych ochotników do przybliżonej ilości poborowych, gdyż w tym wypadku zajął on szóste miejsce, wyprzedzając jedynie OG Kielce i OG Lublin. Z kolei pod względem klasyfikacji ochotników według ich stanu zdrowia, to na 13391 mężczyzn przyjętych w OGŁ kategorię A - tzn. zdolny do służby frontowej - otrzymało 10211 ochotników (76,2\%), kategorię C1 - tzn. zdolny do służby garnizonowej - 2283 (17,1\%) oraz kategorię C2 - tzn. zdolny do służby kancelaryjnej - 897 (6,7 \%). Dla porównania procentowy udział ochotników z kategorią A w innych okręgach wynosił: OG Warszawa - 88,6 \%, OG Lublin 87,3 \%, OG Lwów - 82,3 \%, OG Pomorze - 81,4 \%, OG Poznań - 79,6 \%, OG Kielce - 78,6 \% i OG Kraków - 70,1 \%. Oznaczało to, że stan zdrowotny ochotników z obszaru OGŁ - w porównaniu do pozostałych okręgów nie stał na najlepszym poziomie ${ }^{25}$.

W okresie od 10 lipca do 30 września natężenie zaciągu ochotniczego na obszarze OGŁ systematycznie malało z 5613 ochotników w pierwszym tygodniu zaciągu do 48 i 12 ochotników w ostatnich dwóch tygodniach września. Ogółem spośród 13391 ochotników przyjętych do wojska w OGŁ aż 6 857 (51,2\%) wcielono do oddziałów piechoty, 2297 (17,2\%) - do wojsk technicznych, 1898 (14,2\%) - do wojsk wartowniczych, 646 (4,8\%) do artylerii, $645(4,8 \%)$ - do różnego rodzaju dowództw jako tzw. siły kancela-

\footnotetext{
${ }^{25}$ Tamże, s. 40-41 i 50-51.
} 
Tabela 3. Ogólne zestawienie liczbowe zaciągu do Armii Ochotniczej w OGŁ w 1920 r.

\begin{tabular}{|c|c|c|c|c|c|c|c|c|c|c|c|c|c|}
\hline $\begin{array}{l}\text { RODZAJE BRONI } \\
\text { I KATEGORIE }\end{array}$ & $\begin{array}{c}10-16 \\
V \| I\end{array}$ & $\begin{array}{c}17-23 \\
V \| I\end{array}$ & $24-30 \mathrm{VII}$ & $\begin{array}{c}31 \mathrm{VII}- \\
6 \mathrm{VIII}\end{array}$ & $\begin{array}{l}7-13 \\
V I I I\end{array}$ & $\begin{array}{c}14-20 \\
V I I I\end{array}$ & $\begin{array}{c}21-27 \\
V I I I\end{array}$ & $\begin{array}{l}28 V I I I \\
-3 I X\end{array}$ & $4-10 I X$ & $\begin{array}{l}11-17 \\
I X\end{array}$ & $\begin{array}{c}18-24 \\
\text { IX }\end{array}$ & $\begin{array}{l}25-30 \\
I X\end{array}$ & Razem \\
\hline Piechota & 3118 & 1244 & 710 & 832 & 425 & 218 & 154 & 82 & 21 & 21 & 25 & 7 & 6857 \\
\hline Jazda & 129 & 106 & 77 & 54 & 45 & 38 & 40 & 17 & 3 & 1 & 2 & - & 512 \\
\hline Artyleria & 159 & 197 & 74 & 83 & 58 & 26 & 29 & 8 & 4 & 5 & - & 3 & 546 \\
\hline $\begin{array}{l}\text { Wojska technicz- } \\
\text { ne }\end{array}$ & 845 & 819 & 146 & 126 & 105 & 101 & 52 & 43 & 17 & 31 & 11 & 1 & 2297 \\
\hline $\begin{array}{l}\text { Wojska wartow- } \\
\text { nicze }\end{array}$ & 934 & 415 & 126 & 185 & 117 & 64 & 34 & 10 & 4 & 2 & 6 & 1 & 1898 \\
\hline Inne formacje & 51 & 145 & 58 & 163 & 45 & 31 & 20 & 13 & 6 & 2 & 2 & - & 536 \\
\hline $\begin{array}{l}\text { Tzw. siła kancela- } \\
\text { ryjna }\end{array}$ & 377 & 115 & 55 & 46 & 21 & 9 & 13 & 2 & 3 & 2 & 2 & - & 645 \\
\hline Ogółem & 5613 & 3041 & 1246 & 1489 & 816 & 487 & 342 & 175 & 58 & 64 & 48 & 12 & 13391 \\
\hline \multicolumn{14}{|l|}{ W tym: } \\
\hline Chrześcijanie & 5448 & 2904 & 1175 & 1443 & 798 & 477 & 333 & 171 & 56 & 63 & 47 & 12 & 12927 \\
\hline Niechrześcijanie & 165 & 137 & 71 & 46 & 18 & 10 & 9 & 4 & 2 & 1 & 1 & - & 464 \\
\hline Byłych oficerów & 11 & 6 & 2 & 3 & 3 & - & 1 & - & - & - & - & - & 26 \\
\hline Inni byli wojskowi & 797 & 432 & 177 & 211 & 116 & 69 & 29 & 22 & 18 & 19 & 9 & 2 & 1901 \\
\hline Niewojskowych & 4805 & 2603 & 1067 & 1275 & 697 & 418 & 312 & 153 & 40 & 45 & 39 & 10 & 11436 \\
\hline
\end{tabular}

Źródło: Obrona państwa w 1920, s. 36.

ryjne, $536(4,0 \%)$ - do innych formacji (np. wojska taborowe, etapowe)i $512(3,8 \%)$ - do kawalerii. Największe nasilenie akcji zaciągowej miało miejsce w 2. połowie lipca i na początku sierpnia 1920 r., potem liczba ochotników dość systematycznie malała. Według danych za 3. dekadę lipca do jednostek stacjonujących na obszarze OGŁ zostało wcielonych łącznie 2980 ochotników, czyli aż 22,2\% spośród wszystkich przyjętych od lipca do października tego roku. Spośród nich ponad $40 \%$ stanowili ochotnicy, którzy głosili się do łódzkich oddziałów zapasowych (1322 ochotników). Oczywiście są to dane przykładowe, w kolejnych zaś tygodniach wielkości te ulegały ciągłym zmianom, ze stałą tendencją malejącą ${ }^{26}$.

\footnotetext{
${ }^{26}$ Tamże, s. 42, 46-49.
} 
Tabela 4. Zestawienie ilościowe zaciągu ochotniczego w 0GŁ w dniach 20-31 VII 1920 r.

\begin{tabular}{|c|c|c|c|c|c|c|c|c|c|c|c|c|}
\hline Wyszczególnienie & 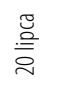 & 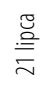 & 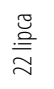 & $\frac{\widetilde{\widetilde{\sigma}}}{\approx}$ & 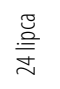 & 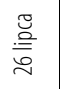 & 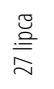 & $\underset{\substack{\stackrel{\mathscr{m}}{D} \\
\sim}}{\sim}$ & 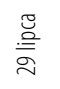 & $\frac{\widetilde{\Xi}}{\overline{\frac{\sigma}{m}}}$ & $\frac{\stackrel{\widetilde{\Xi}}{=}}{\stackrel{m}{m}}$ & $\begin{array}{l}\mathbf{E} \\
\text { Ẽ్ }\end{array}$ \\
\hline Batalion Zapasowy 10 pp & 18 & 7 & 8 & 9 & 4 & - & 9 & 7 & 16 & 6 & 5 & 89 \\
\hline Batalion Zapasowy 14 pp & 52 & 39 & 72 & 36 & 16 & 19 & 15 & 21 & 14 & - & 11 & 295 \\
\hline Batalion Zapasowy 18 pp & 126 & 26 & 16 & 17 & 20 & 26 & 28 & 20 & 43 & 10 & 8 & 340 \\
\hline Batalion Zapasowy 28 pSK & 31 & 20 & 24 & 16 & 20 & 15 & 10 & 18 & - & 12 & 8 & 174 \\
\hline Batalion Zapasowy 29 pSK & 86 & 49 & 37 & 26 & 7 & 28 & 23 & 10 & 30 & 29 & 23 & 348 \\
\hline Batalion Zapasowy 30 pSK & 45 & 18 & 10 & 7 & 13 & 15 & - & 7 & 5 & 13 & 2 & 135 \\
\hline Batalion Zapasowy 31 pSK & 21 & 78 & 27 & 24 & 27 & 25 & 19 & 8 & 21 & 14 & 14 & 278 \\
\hline Batalion Zapasowy 37 pp & 37 & 26 & 9 & 6 & 8 & 7 & 15 & 9 & 4 & 4 & 13 & 138 \\
\hline Szwadron Zapasowy 3 Pułku Ułanów & 88 & 95 & - & - & 5 & 7 & 3 & 2 & 10 & 9 & 56 & 275 \\
\hline Bateria Zapasowa 10 pap & 6 & - & - & 6 & - & 1 & 6 & 1 & 3 & - & 1 & 24 \\
\hline Bateria Zapasowa 10 pac & - & 3 & - & 2 & 4 & - & 4 & - & 1 & 1 & - & 15 \\
\hline Bateria Zapasowa 4 pap & - & 12 & - & - & - & - & - & 3 & - & - & - & 15 \\
\hline Bateria Zapasowa 4 pac & 3 & - & - & - & - & - & - & 1 & 2 & 2 & - & 8 \\
\hline $\begin{array}{l}\text { Batalion Zapasowy IV Batalionu Wojsk Wartowni- } \\
\text { czych i Etapowych }\end{array}$ & - & 17 & - & - & 81 & 47 & 34 & 19 & 7 & 9 & 61 & 275 \\
\hline $\begin{array}{l}\text { Kolumna Zapasowa } 4 \text { Dywizjonu Samochodo- } \\
\text { wego }\end{array}$ & - & 62 & - & 19 & 12 & - & 19 & 15 & - & 8 & - & 135 \\
\hline Kompania Zapasowa 4 Batalionu Telegraficznego & 15 & 76 & 17 & 16 & 24 & 23 & 4 & - & - & - & - & 175 \\
\hline Szwadron Zapasowy 4 Dywizjonu Taborowego & - & 8 & - & 2 & 12 & 12 & 4 & 2 & 1 & 2 & 10 & 53 \\
\hline Batalion Zapasowy Wojsk Kolejowych nr 3 & - & - & - & 12 & - & - & 9 & 27 & 7 & 4 & 17 & 76 \\
\hline Kompania Zapasowa 1 Pułku Czołgów & 1 & 7 & - & 3 & 3 & 2 & 1 & 4 & 1 & 8 & - & 30 \\
\hline $\begin{array}{l}\text { Szwadron Zapasowy } 3 \text { Pułku Szwoleżerów (cza- } \\
\text { sowo stacjonujący we Włocławku) }\end{array}$ & - & 22 & 34 & 34 & - & - & 1 & - & 7 & 4 & - & 102 \\
\hline Szwadron Zapasowy 4 Dywizjonu Żandarmerii & - & - & - & - & - & - & - & - & - & - & - & - \\
\hline Ogółem & 529 & 565 & 254 & 235 & 256 & 227 & 204 & 174 & 172 & 135 & 229 & 2980 \\
\hline
\end{tabular}

Źródło: CAW WBH, Okręg Korpusu nr IV Łódź, sygn. I.371.4, t. 15. Meldunki o zaciągu ochotniczych z oddziałów zapasowych stacjonujących na obszarze 0GŁ za okres 20-31 VII 1921 r.

Ciekawych danych w odniesieniu do pochodzenia społecznego ochotników dostarcza sprawozdanie Okręgowego Inspektoratu Armii Ochotniczej 
w Łodzi, z którego wynika, że zdecydowaną większość - bo aż 45\% - stanowili robotnicy (6 034 osób), osoby wywodzące się z inteligencji (głównie młodzież szkół średnich) to niemal 37\% ochotników (4 954 osób), natomiast rolnicy (określani wówczas mianem włościan) stanowili jedynie 16 \% (2 123 osób). Pozostała część - wynosząca około $2 \%$ - to osoby bez żadnego zawodu (ogółem 280 ochotników). Stosunkowo mała liczba ochotników wywodzących się ze środowiska wiejskiego była spowodowana trwającymi w tym czasie pracami żniwnymi, jak również niezrozumieniem sensu toczonej wojny przez część chłopów oraz propagandą bolszewicką, głoszoną przez agitatorów komunistycznych, czemu aktywnie przeciwdziałała Policja Państwowa oraz żandarmeria wojskowa. Z kolei duży odsetek robotników wynikał z aktywnej działalności propagandowej na rzecz werbunku do Armii Ochotniczej prowadzonej przez związki zawodowe i partie polityczne ${ }^{27}$.

Dużym problemem związanym $\mathrm{z}$ tworzeniem oddziałów ochotniczych w OGŁ był brak wystarczającej ilości broni, lecz należy pamiętać, że podobne braki odczuwały nie tylko organizowane wcześniej formacje rezerwowe, ale także i jednostki frontowe. W tej sytuacji władze wojskowe apelowały do ludności cywilnej o przekazywanie dla potrzeb wojska posiadanej w domu broni i elementów wyposażenia wojskowego. Jako przykład można tu podać rozkaz kpt. Alfreda Biłyka (dowódcy Miasta Łodzi) z 15 lipca 1920 r.:

Na mocy rozkazu Dowództwa Okręgu Generalnego Łódzkiego L.dz. 104/VII został zarządzony natychmiastowy wykup szabel i pałaszy wszelkiego typu i rodzaju zdolnych do użytku bojowego, a znajdujących się w posiadaniu oficerów i szeregowych. Wyjątek stanowi broń mająca wartość historyczną, tudzież broń znajdująca się w posiadaniu oficerów i szeregowych formacji zapasowych jazdy strzelców granicznych i żandarmerii ${ }^{28}$.

Podobne apele ponawiano w kolejnych dniach, jak np. w rozkazie Komendy Miasta Łódź z 30 lipca:

Bardzo duża ilość karabinów i karabinków różnych systemów i wzorów znajduje się u oficerów i osób prywatnych, jako zdobyte w walkach, czy też pamiątkowe itp. Dziś, kiedy zależy omal że na każdym karabinie, wszyscy (w pierwszym zaś rzędzie oficerowie) muszą oddać przechowywaną bezużytecznie broń dla uzbrojenia armji ${ }^{29}$.

\footnotetext{
${ }^{27}$ Tamże, s. 107-108.

${ }^{28}$ CAW WBH, Okręg Korpusu nr IV Łódź, sygn. I.371.4.1, Rozkaz kpt. Alfreda Biłyka z 15 VII $1920 \mathrm{r}$.

${ }^{29}$ CAW WBH, Komenda Garnizonu Łódź, sygn. I.372.34.7, Rozkaz Dowództwa Miasta Łodzi nr 212 z 30 VII 1920 r.
} 
Dużym problemem było także zapewnienie ochotnikom odpowiedniego umundurowania i niezbędnego wyposażenia, przez co wielu z nich po zgłoszeniu się do Armii Ochotniczej chodziło początkowo w ubraniach cywilnych, do których doszywano biało-czerwoną kokardę.

Innym elementem działalności Inspektoratu Okręgowego Armii Ochotniczej w Łodzi było kontrolowanie warunków bytowych żołnierzy-ochotników w oddziałach zapasowych, które zazwyczaj nie były najlepsze. Wykryte niedociągnięcia $\mathrm{w}$ tym zakresie starano się szybko naprawiać za pośrednictwem Dowództwa OGŁ. Ogółem w jednostkach zapasowych stacjonujących na obszarze okręgu z inicjatywy Inspektoratu Okręgowego Armii Ochotniczej przeprowadzono ponad 120 inspekcji. Nie mniej istotnym elementem w działalności Inspektoratu było prowadzenie propagandy wśród ochotników przyjętych do wojska. Miała ona na celu utrzymanie na wysokim poziomie morale i dyscypliny wojskowej. W tym celu rozprowadzano wśród żołnierzy materiały propagandowe otrzymywane z Głównego Inspektoratu Armii Ochotniczej. Ogółem w oddziałach zapasowych stacjonujących w OGŁ rozdano ponad 9 tys. sztuk różnego rodzaju pism i broszur (w tym m.in. takie jak „Ochotnik”, „Wesoły Wojak”, „Łazik” czy „Gazeta Polowa”) oraz 2 tys. plakatów propagandowych ${ }^{30}$.

W lipcu 1920 r. Okręgowy Inspektorat Armii Ochotniczej przy Dowództwie OGŁ, wraz z dowództwem okręgu, przystąpił - jak wspomniano - do prac związanych $\mathrm{z}$ formowaniem jednostek ochotniczych, tj. planowanych ośmiu pułków piechoty i jednego pułku jazdy: 210 pp przez Batalion Zapasowy $10 \mathrm{pp}$ w Łowiczu, 214 pp przez Batalion Zapasowy $14 \mathrm{pp}$ we Włocławku, 218 pp przez Batalion Zapasowy 18 pp w Koninie, 228 pp przez Batalion Zapasowy 28 pSK w Lodzi, 229 pp przez Batalion Zapasowy 29 pSK w Kaliszu, 230 pp przez Batalion Zapasowy 30 pSK w Tomaszowie Mazowieckim, 231 pp przez Batalion Zapasowy 31 pSK w Łodzi i 237 pp przez Batalion Zapasowy 37 pp w Kutnie oraz 203 Pułku Ułanów przez Szwadron Zapasowy 3 Pułku Ułanów w Kaliszu. Przy pozostałych oddziałach zapasowych nie planowano formować odrębnych pododdziałów ochotniczych, przybyłych zaś do nich ochotników wykorzystano do uzupełnienia stanów osobowych tworzonych w nich kompani marszowych. Etat ochotniczego pułku piechoty był podobny do pułku liniowego, lecz bez kompanii technicznej ${ }^{31}$.

\footnotetext{
${ }^{30}$ CAW WBH, Okręg Korpusu nr IV Łódź, sygn. I.371.4.16, Sprawozdanie z działalności Okręgowego Inspektoratu Armii Ochotniczej w Łodzi z 21 X 1921 r.

${ }^{31}$ CAW WBH, Dziennik Rozkazów Dowództwa OGŁ, Rozkaz tajny oficerski nr 47 z 23 VI 1920 r.; Obrona państwa w 1920, s. 58-59.
} 
Szybko się jednak okazało, że powyższych - nazbyt optymistycznych założeń nie udało się zrealizować z uwagi na niewystarczającą liczbę ochotników oraz braki w ekwipunku wojskowym. Na przykład w okresie od 17 do 30 lipca 1920 r. do Batalionu Zapasowego 28 pSK w Lodzi zgłosiło się 2 oficerów i 446 szeregowych, co pozwoliło sformować jedynie dwie kompanie ochotnicze (1 kompania dowodzona przez por. Tadeusza Jarosza liczyła 222 ochotników, a 2 kompania dowodzona przez ppor. Teofila Reszkę 224 żołnierzy), natomiast do Batalionu Zapasowego 29 pSK w Kaliszu zgłosiło się w tym okresie 3 oficerów, 16 podoficerów i 477 szeregowych, z których utworzono trzy kompanie marszowe (1 kompanią dowodził ppor. Bolesław Męciwoda-Wodecki, 2 kompanią - ppor. Marek Ptaszkowski, a 3 kompanią - ppor. Leszek Skrzetuski). W tej sytuacji nic dziwnego, że władze wojskowe zmieniły powyższe założenia, godząc się na formowanie przez część oddziałów zapasowych piechoty po jednym batalionie ochotniczym. W praktyce i tego nie udało się zrealizować, gdyż ostatecznie na obszarze OGŁ sformowano - jako zwarte pododdziały - jedynie trzy bataliony ochotnicze (dwa w ochotniczym 231 pp i jeden w ochotniczym 229 pp) oraz 21 samodzielnych kompanii ochotniczych. Na słabe wyniki tworzenia oddziałów ochotniczych niewątpliwie wpłynęły bieżące potrzeby frontowe, gdyż część przyjętych ochotników kierowano - w myśl zarządzeń MSWojsk. bezpośrednio do różnych jednostek walczących na froncie w formie uzupełnień lub do dyspozycji NDWP. W rezultacie na obszarze okręgu nie udało się utworzyć ani jednego w pełni zorganizowanego pułku piechoty ochotniczej, a jedynie mniejsze pododdziały ${ }^{32}$.

W sformowanych na obszarze OGŁ ochotniczych oddziałach piechoty znalazło się łącznie 5122 żołnierzy. Najlepsze wyniki pod tym względem osiągnął Batalion Zapasowy 31 pSK w Łodzi, któremu udało się zorganizować dwa bataliony ochotniczego $231 \mathrm{pp}$ oraz cztery samodzielne ochotnicze kompanie piechoty, które wysłano do dyspozycji NDWP (jako samodzielna jednostka ochotnicza w walkach wziął udział jedynie I batalion 231 ochotniczego pp). Z kolei przy Batalionie Zapasowym 29 pSK w Kaliszu sformowano jeden batalion ochotniczego 229 pp oraz dwie samodzielne ochotnicze kompanie piechoty, które również skierowano do dyspozycji NDWP. Natomiast w przypadku pozostałych oddziałów zapasowych udało się utworzyć w nich jedynie od jednej do czterech kompanii ochotniczych, które niemal

\footnotetext{
${ }^{32}$ CAW WBH, Okręg Korpusu nr IV Łódź, sygn. I.371.4.16, Meldunki o zaciągu ochotników Batalionu Zapasowego 28 pSK i Batalionu Zapasowego 29 pSK za okres od 17 do 30 VII $1920 \mathrm{r}$.
} 
natychmiast wysyłano na front (część z tych kompanii wzięła aktywny udział w obronie dolnej Wisły jako tzw. kompanie alarmowe) ${ }^{33}$.

Tabela 5. Ochotnicze oddziały piechoty sformowane na obszarze OGŁ latem $1920 \mathrm{r}$.

\begin{tabular}{|c|c|c|c|c|c|}
\hline \multirow{2}{*}{$\begin{array}{l}\text { NAZWA TWORZONEGO } \\
\text { ODDZIAŁU }\end{array}$} & \multirow{2}{*}{ MIEJSCE FORMOWANIA } & \multirow{2}{*}{$\begin{array}{l}\text { ORGANIZOWANY PRZEZ } \\
\text { BATALION ZAPASOWY }\end{array}$} & \multicolumn{2}{|c|}{ SFORMOWANE FORMACJE OCHOTNICZE PIECHOTY } & \multirow{2}{*}{$\begin{array}{c}\text { OGÓLNY STAN } \\
\text { LUDZI }\end{array}$} \\
\hline & & & Bataliony & $\begin{array}{l}\text { SamodzleLNE } \\
\text { Kompanle }\end{array}$ & \\
\hline $210 \mathrm{pp}$ & Łowicz & $10 \mathrm{pp}$ & - & 1 & 96 \\
\hline $214 \mathrm{pp}$ & Włocławek & $14 p p$ & - & 4 & 392 \\
\hline $218 \mathrm{pp}$ & Konin & $18 \mathrm{pp}$ & - & 1 & 96 \\
\hline $228 \mathrm{pp}$ & Łódź & $28 \mathrm{pSK}$ & - & 4 & 642 \\
\hline $229 \mathrm{pp}$ & Kalisz & $29 \mathrm{pSK}$ & 1 & 2 & 1092 \\
\hline $230 \mathrm{pp}$ & Tomaszów Mazowiecki & $30 \mathrm{psk}$ & - & 1 & 96 \\
\hline $231 \mathrm{pp}$ & Łódź & 31 pSk & 2 & 4 & 2298 \\
\hline $237 \mathrm{pp}$ & Kutno & $37 \mathrm{pp}$ & - & 4 & 410 \\
\hline \multicolumn{3}{|c|}{ Razem w ośmiu batalionach zapasowych } & 3 & 21 & 5122 \\
\hline
\end{tabular}

Źródło: Obrona państwa w 1920, s. 43-44.

Poza ochotniczymi oddziałami piechoty sformowano również, w oparciu o Szwadron Zapasowy 3 Pułku Ułanów w Kaliszu, ochotniczy 203 Pułk Ułanów. Powstał on - na mocy rozkazu MSWojsk. z 27 lipca 1920 r. - na bazie szwadronu marszowego oraz szwadronów ochotniczych (kaliskiego, sieradzkiego i łęczyckiego). Jego pierwszym dowódcą został rtm. Adam Zakrzewski, a 2 sierpnia dowództwo ochotniczego 203 Pułku Ułanów objął mjr Zygmunt Podhorski, który przyjął w tym dniu uroczystą przysięgę jednostki. Liczyła ona wówczas 27 oficerów i 716 szeregowych, w tym 20 oficerów, 120 podoficerów i 540 ułanów z zaciągu ochotniczego (oprócz 512 ochotników, którzy zgłosili się do Szwadronu Zapasowego 3 Pułku Ułanów, przydzielono także 168 ochotników spoza OGŁ). Pułk ten na początku sierpnia włączono najpierw do VIII, a następnie IX Brygady Jazdy, po czym 15 I 1921 r. przemianowano na 27 Pułk Ułanów ${ }^{34}$.

${ }^{33}$ Obrona państwa $w$ 1920, s. 43-44; Księga Chwaty Piechoty, red. B. Prugar-Ketling, Warszawa 1937-1939, s. 226; W. JARNO, Strzelcy Kaniowscy w latach 1919-1939, Warszawa 2004, s. 146-147; K. CZERNIELEWSKI, W. JARNO, Garnizon tódzki, s. 170-171.

${ }^{34}$ S. RaChalewski, Szabla na kilimie. Ze szwadronami 203 Pułku Ułanów w roku 1920, 
W pozostałych oddziałach zapasowych znajdujących się na obszarze OGŁ - z braku wystarczającej liczby ochotników - nie tworzono odrębnych pododdziałów ochotniczych, lecz przybywających ochotników wcielano w formie uzupełnień do tworzonych w nich pododdziałów marszowych. Jedynym wyjątkiem była Bateria Zapasowa 10 pap w Łodzi, gdzie z przybyłych do niej ochotników odtworzono 6 baterię rozbitą na froncie na początku sierpnia 1920 r. (21 października tego roku dołączyła do własnego pułku przebywającego w rejonie Brześcia nad Bugiem), pozostałych zaś ochotników wcielono do formowanego w tym czasie od podstaw III dywizjonu 10 pap $^{35}$. Ogółem spośród 13391 ochotników przyjętych do wojska na obszarze OGŁ zdecydowana większość - bo aż 11 578, czyli 86,4\% - została wysłana na front, gdzie szybko wcielono ich, w formie uzupełnień, do różnych jednostek wojskowych. Pozostałą część ochotników wcielono do formacji wartowniczych i etapowych ${ }^{36}$. Oto, co na temat przydatności sformowanych w OGŁ pododdziałów ochotniczych zawarto w sprawozdaniu z działalności Okręgowego Inspektoratu Armii Ochotniczej w Lodzi:

Zaznacza się, że materiał żołnierski ochotniczy został zużytkowany w przeważającej części na zasilenie marszówek, część została wysłana do innych Okręgów Generalnych, z tych około 2000 ochotników z Okręgu Generalnego Łódź najlepiej wyszkolonych i wyćwiczonych wysłano do Brygady Syberyjskiej (...) Jako formacje o charakterze ochotniczym odeszły w pole baon I/231 pp i 203 pułk ułanów ${ }^{37}$.

W trakcie zaciągu do Armii Ochotniczej w OGŁ nie wszystko jednak funkcjonowało dobrze, gdyż pełnomocnik Obywatelskiego Komitetu Wykonawczego Armii Ochotniczej na Województwo Łódzkiego (A. Kamieński wojewoda łódzki) napotykał w swej działalności w zakresie agitacji na rzecz wstępowania do niej ochotników wiele problemów, czego potwierdzeniem może być rozkaz Dowództwa Miasta Łodzi z 5 sierpnia 1920 r.:

Obywatelski Komitet Wykonawczy zwrócił się do P. Ministra Spraw Wojskowych z powiadomieniem, że w sprawach tyczących się Armii Ochotniczej, oraz opieki

Łódź 1938, s. 44-56; Z. GNAT-WieteSKA, 27 Pułk Utanów im. Króla Stefana Batorego, Warszawa 1992, s. 6-8; B. DoBRZYŃSKi, Zarys historii wojennej 3 Pułku Ułanów, Warszawa 1929, s. 13; Obrona państwa $w$ 1920, s. 46; S. RostworowsKI, Zarys historii wojennej 27 Pułku Ułanów (b. 203 Ochotniczego Pułku Ułanów), Warszawa 1920, s. 5-9.

${ }^{35}$ R. Leroch-Orlot, Zarys historii wojennej 10 Pułku Kaniowskiego Artylerii Polowej, Warszawa 1929, s. 39-40; P. Zarzycki, 10 Kaniowski Puk Artylerii Lekkiej, Pruszków 1997, s. 10.

${ }^{36}$ Obrona państwa w 1920, s. 108.

${ }^{37}$ CAW WBH, Okręg Korpusu nr IV Łódź, sygn. I.371.4.16, Sprawozdanie z działalności Okręgowego Inspektoratu Armii Ochotniczej w Łodzi z 21 X 1921 r. 
nad żołnierzem, a nawet $\mathrm{w}$ sprawach ściśle $\mathrm{z}$ armią czynną związanych, są robione społeczeństwu trudności, które hamują ofiarność czynu i mienia, wprowadzają w zamęt i zniechęcenie. Wobec powyższego poszczególne D-twa dołożą starań, by działalności Obywatelskiego Komitetu Wykonawczego Obrony Państwa nie były stawiane żadne utrudnienia i przeszkody. O wszelkich wykroczeniach przeciw rozkazom dotyczącym Armji Ochotniczej, które by mogły zniechęcić obywateli do zgłaszania się do tejże armii, lub zmniejszyć ich ofiarność, należy donieść do D-twa Miasta ${ }^{38}$.

Niestety, w rozkazie tym nie doprecyzowano, o jakich trudnościach była mowa. Prawdopodobnie chodziło o propagandę komunistyczną, szerzącą się w miastach i w środowisku wiejskim, oraz niechęć części ludności do wstępowania w szeregi Armii Ochotniczej, wynikającą najczęściej z niezrozumienia powagi sytuacji. Oto, co na ten temat można znaleźć w „Komunikacie informacyjnym" MSWojsk. z 20 lipca 1920 r.:

Większe miasta wykazują duży zapał, podniecany przez liczne wiece werbunkowe, zwoływane przez wszystkie partie, począwszy od ND [Narodowej Demokracji - W.J.] kończąc na PPS. Ta ostatnia popiera w zdecydowany sposób akcję zaciągową, jednocześnie jednak wysuwa na czoło odezw werbunkowych hasło pokoju z bolszewikami oraz domaga się radykalnej zmiany rządu, akcentując stale swój bezwzględnie opozycyjny stosunek do rządu «antyrobotniczego». [...] Jednocześnie z akcją patriotyczną wzmaga się agitacja komunistyczna przeciwko poborowi. Żywioły bolszewickie zręcznie wyzyskują sytuację na froncie i dążą za wszelką cenę do wywołania paniki przy pomocy licznych odezw zapowiadających bliski przewrót socjalny, nawołujących żołnierzy do tworzenia rad delegatów, do skierowania broni przeciwko ich dowódcom itp. Wewnątrz wojska agitacja ta nie odnosi skutku. Natomiast trafia ona na podatny grunt wśród ludności wiejskiej Galicji, a ostatnio i Kongresówki ${ }^{39}$.

O ile więc w miastach akcja zaciągu do Armii Ochotniczej patriotycznie nastawionych mieszczan i części robotników przynosiła dość dobre efekty, to w środowisku wiejskim dość długo trwało, zanim chłopi w większym stopniu zaczęli ochotniczo zgłaszać się do wojska, czego potwierdzenie można znaleźć w „Komunikacie Informacyjnym” MSWojsk. z 15 sierpnia:

Chłopi, niekiedy nawet należący do elity chłopskiej, delegaci kółek rolniczych nie kryją obojętności dla losów państwa, oddzielając interesy swego stanu od interesów narodu. W tych warunkach hasło zaciągu ochotniczego, rzucone w początku

${ }^{38}$ CAW WBH, Komenda Garnizonu Łódź, sygn. I.372.34.7, Rozkaz Dowództwa Miasta Łodzi nr 218 z 5 VIII 1920 r.

${ }^{39}$ Komunikat informacyjny MSWojsk. nr 40 z 20 VII 1920 r., w: O Niepodległa i granice, t. II: Raporty i komunikaty naczelnych władz wojskowych o sytuacji wewnętrznej Polski 19191920, oprac. M. Jabłonowski, P. Stawecki, T. Wawrzyński, Warszawa-Pułtusk 2000, s. 495. 
ubiegłego miesiąca, natrafiło zrazu na wsi na grunt wysoce niepodatny. Masa chłopska bardzo słabo zareagowała na odezwy naczelnika i ROP [Rady Obrony Państwa - W.J.]. Ale szybko rozwijające się wypadki przemówiły z siłą elementarną, dość silnie, aby i wieś drgnęła. W drugiej połowie lipca meldunki napływające se wszystkich DOGenów zaczynają donosić o widocznej zmianie w nastroju wsi. [...] Co się tyczy zaciągu ochotniczego, to wieś mimo widocznej poprawy $\mathrm{w}$ tej dziedzinie, $\mathrm{w}$ dalszym ciągu, znacznie $\mathrm{w}$ tyle za miastem ${ }^{40}$.

Pomimo wszystko akcja zaciągu ochotniczego w OGŁ pozwoliła na wzmocnienie polskiej armii niemal 13,4 tys. ochotników, wliczając zaś harcerzy - liczba ta sięgnęła niemal 14 tys. Główną rolę w działalności propagandowej na rzecz wstępowania w szeregi Armii Ochotniczej odegrał Wydział II sztabu Dowództwa OGŁ kierowany przez kpt. Stefana Cieślaka, któremu minister spraw wojskowych gen. por. Kazimierz Sosnkowski przesłał 13 sierpnia specjalną pochwałę za to, że: ,[...] rozwinął intensywną akcję propagandystyczną, przeprowadzając ją w sposób pomysłowy, dzięki czemu dała bardzo dodatnie wyniki" ${ }^{41}$. Odrębną pochwałę otrzymał także kierownik Referatu Propagandy tego Wydziału szeregowiec-ochotnik Zygmunt Lorentz za - jak to w niej określono: ,[...] wzbudzenie w społeczeństwie i żołnierzu ducha zapału patriotycznego i ofiarności obywatelskiej oraz przeciwdziałanie szerzącym się podówczas zgubnym nastrojom niewiary i zwątpienia we własne siły" 42 .

Działalność Okręgowego Inspektoratu Armii Ochotniczej w Łodzi trwała do początków października 1920 r., kiedy to w związku z klęską Armii Czerwonej pod Warszawą i nad Niemnem oraz zawarciem rozejmu ustało zagrożenie rosyjskie. Rozwiązano wówczas zarówno Generalny Inspektorat Armii Ochotniczej, jak i istniejące inspektoraty przy dowództwach Okręgów Generalnych. Pomimo krótkiego okresu istnienia inspektorat ten zapisał się w pamięci ówczesnych mieszkańców regionu łódzkiego, spełniając zarazem ważną rolę w obronie odzyskanej dwa lata wcześniej niepodległości. Niestety z działalności Okręgowego Inspektoratu Armii Ochotniczej przy Dowództwie OGŁ i tworzonych na obszarze tego okręgu oddziałów ochotniczych zachowały się nieliczne dokumenty, które nie pozwalają na dokładne odtworzenie jego funkcjonowania i procesu tworzenia formacji ochotniczych. Warto jednak przypomnieć, że z ochotników niezakwalifikowanych do służby li-

\footnotetext{
${ }^{40}$ Komunikat informacyjny MSWojsk. nr 45 z 15 VIII 1920 r., w: O Niepodległa i granice, s. 520 .

${ }^{41}$ CAW WBH, Dziennik Rozkazów Dowództwa OGŁ, Rozkaz nr 118 z 1 IX 1920 r.

${ }^{42}$ CAW WBH, Dziennik Rozkazów Dowództwa OGŁ, Rozkaz nr 161 z 9 XII 1920 r.
} 
niowej tworzono zazwyczaj pododdziały wartownicze, co pozwalało skierować do walki wielu żołnierzy zajmujących się wczesniej ochroną obiektów wojskowych na głębokim zapleczu frontu. Tym samym nawet i ci ochotnicy - choć pośrednio - wnieśli również istotny wkład w ostateczne zwycięstwo w wojnie polsko-bolszewickiej. Przebieg zaciągu ochotniczego - biorąc pod uwagę czas jego trwania, wynoszący niespełna trzy miesiące - można jednak uznać za sukces polskich władz wojskowych, gdyż ochotnicy wzmocnili regularną armię w krytycznym momencie wojny. Również społeczeństwo pokazało, że w chwilach najważniejszych dla losów Polski zdolne jest do wielkich poświęceń w imię obrony niepodległości kraju. W tym procesie także region łódzki miał znaczący udział.

\section{BIBLIOGRAFIA}

ARCHIWALIA

Centralne Archiwum Wojskowe Wojskowego Biura Historycznego w Warszawie:

Okręg Korpusu nr IV Łódź, sygn. I.371.4.1 i I.371.4.16.

Komenda Garnizonu Łódź, sygn. I.372.34.7.

Dziennik Rozkazów Dowództwa OGŁ z 1920 r.

Akta personalne Michała Zienkiewicza, ap. I.480.505.

Archiwum Państwowe w Łodzi:

Zbiór druków i pism ulotnych, sygn. 575/394.

\section{ŹRÓDŁA DRUKOWANE}

O Niepodległa i granice, t. II: Raporty i komunikaty naczelnych władz wojskowych o sytuacji wewnętrznej Polski 1919-1920, oprac. Marek Jabłonowski, Piotr Stawecki, Tadeusz Wawrzyński, Warszawa-Pułtusk: Akademia Humanistyczna im. A. Gieysztora 2000.

„Dziennik Łódzki” 1990.

CZASOPISMA

„Echo” 1920.

„Głos Polski” 1920.

„Harcerstwo” 1993.

„Rocznik Łódzki” 1978.

„Rozwój” 1920.

\section{OPRACOWANIA}

Ajnenkiel Eugeniusz, WarężAK Jan, Łódź w walce o niepodległość Polski, Łódź 1938.

BŁAżEJEWsKi Wacław, $Z$ dziejów harcerstwa polskiego (1910-1939), Warszawa: Młodzieżowa Agencja Wydawnicza 1985.

CZernielewski Konrad, Jarno Witold, Garnizon łódzki Wojska Polskiego 1918-1939, Toruń: Wydawnictwo Adam Marszałek 2008. 
DoBRZYŃSKI Bohdan, Zarys historii wojennej 3 Pułku Utanów, Warszawa: Wojskowe Biuro Historyczne 1929.

Gnat-Wieteska Zbigniew, 27 Pułk Ułanów im. Króla Stefana Batorego, Warszawa: P.W. Egross 1992

JARNO Witold, Okręg Korpusu Wojska Polskiego nr IV Łódź 1918-1939, Łódź: Wydawnictwo „Ibidem” 2001.

JARno Witold, Samodzielny Referat Informacyjny Dowództwa Okręgu Korpusu nr IV Łódź w latach 191801939, w: Wywiad i kontrwywiad wojskowy II RP. Z działalności Oddziału II SG $W P$, t. VIII, red. Tadeusz Dubicki, Łomianki: Literackie Towarzystwo Wydawnicze 2017, s. 67-97.

JARNO Witold, Strzelcy Kaniowscy w latach 1919-1939, Warszawa: Wydawnictwo „Trio” 2004.

Księga Chwały Piechoty, red. Bronisław Prugar-Ketling, Warszawa: Dep. Piechoty M. S. Wojsk. 1937-1939.

LEROCH-OrLOT Rudolf, Zarys historii wojennej 10 Pułku Kaniowskiego Artylerii Polowej, Warszawa: Wojskowe Biuro Historyczne 1929.

NeKRASZ Władysław, Harcerze $w$ bojach. Przyczynek do udziału młodzieży polskiej $w$ walkach o niepodległość ojczyzny w latach 1914-1921, Warszawa: Główna Księgarnia Wojskowa 1930.

Obrona państwa w 1920 roku. Ksiega sprawozdawczo-pamiątkowa Generalnego Inspektoratu Armii Ochotniczej i Obywatelskich Komitetów Obrony Państwa, red. Władysław Ścibor-Rylski, Warszawa: Obywatelski Komitet Wykonawczy Obrony Państwa 1923.

RaChalewski Stanisław, Szabla na kilimie. Ze szwadronami 203 Pułku Ułanów w roku 1920, Łódź: Towarzystwo Przyjaciół Miasta Łodzi 1938.

Rostworowski Stanisław, Zarys historii wojennej 27 Pułku Ułanów (b. 203 Ochotniczego Pułku Ułanów), Warszawa: Wojskowe Biuro Historyczne 1920.

SZCZEPKOWSKI Mikołaj J., Zaciag ochotniczy i pobór do wojska na terenie Okręgu Generalnego Łódź w latach 1918-1921, „Rocznik Łódzki” 23 (26) (1978), s. 335-349.

Wrzosek Mieczysław, Wojny o granice Polski Odrodzonej 1918-1921, Warszawa: Wiedza Powszechna 1992.

ZARZYCKI Piotr, 10 Kaniowski Puk Artylerii Lekkiej, Pruszków: Oficyna Wydawnicza „Ajaks” 1997.

\section{ZACIĄG DO ARMII OCHOTNICZEJ \\ W OKRĘGU GENERALNYM WOJSKA POLSKIEGO NR IV ŁÓDŹ LATEM 1920 ROKU}

\section{Streszczenie}

Tematem artykułu jest zaciag do Armii Ochotniczej w Okregu Generalnym nr IV Łódź latem 1920 r. Prowadził go Okręgowy Inspektorat Armii Ochotniczej w Łodzi (jego komendantem był płk Michał Zienkiewicz), który współpracował w tym zakresie z organizacjami społecznymi oraz lokalnymi strukturami partii politycznych. Inspektorat nadzorował prowadzenie agitacji i werbunku oraz proces formowania oddziałów ochotniczych. Armia Ochotnicza miała wzmocnić siłę polskiej armii w najtrudniejszym momencie wojny polsko-bolszewickiej, gdy Armia Czerwona próbowała zająć stolicę Polski. Akcja zaciągu do Armii Ochotniczej w Okręgu Generalnym nr IV Łódź dała polskiej armii niemal 13,4 tys. ochotników, zaś wliczając harcerzy - niemal 14 tys. Początkowo planowano utworzyć osiem ochotniczych pułków piechoty, lecz ostatecznie udało się sformować jedynie dwa niepełnie pułki (nr 229 i 231) oraz 21 samodzielnych kompanii złożonych z ochotników. Poza ochotniczymi oddziałami piechoty, sformowano również ochotniczy 203 Pułku Ułanów w Kaliszu utworzony przez Szwadron Zapasowy 3 Pułku Ułanów. Przebieg 
zaciągu - biorąc pod uwagę krótki czas jego trwania od lipca do września - był sukcesem polskich władz wojskowych, gdyż ochotnicy wzmocnili regularną armię w krytycznym momencie wojny. Również społeczeństwo województwa łódzkiego pokazało, iż w chwilach najważniejszych dla Polski zdolne jest do wielkich poświęceń w imię obrony niepodległości kraju.

Słowa kluczowe: Okręg Generalny Wojska Polskiego nr IV Łódź; wojna polska-bolszewicka; historia Łodzi; Armia Ochotnicza.

\section{ENLISTMENT FOR THE VOLUNTEER ARMY IN THE GENERAL DISTRICT OF THE POLISH ARMY NO. IV LODZ IN THE SUMMER OF 1920}

\section{S u m m a ry}

The subject of the article is the enlistment for the Volunteer Army in District General No. IV Lodz in the summer of 1920. It was run by the Regional Inspectorate of the Volunteer Army in Lodz (its commander was Colonel Michał Zienkiewicz), who cooperated in this regard with social organizations and local structures of political parties. This Inspectorate oversaw the conduct of agitation, recruitment and the process of forming volunteer troops. The Volunteer Army strengthened the Polish Army at the most difficult moment of the Polish-Bolshevik war, when the Red Army tried master the capital of Poland. Recruitment to the Volunteer Army in District General No. IV Lodz gave the Polish army almost 13,400. volunteers, including scouts - almost 14 thousand. Initially, military authorities was planned to create eight volunteer infantry regiments, but eventually were formed only two incompletely regiments (No. 229 and 231) and 21 independent companies consisting of volunteers. Apart from volunteer infantry units, was formed in Kalisz a volunteer 203 Uhlan Regiment, created by the Reserve Squadron of the $3^{\text {rd }}$ Uhlan Regiment. The recruitment to volunteer troops - given its short duration from July to September - was a success for the Polish military authorities, as the volunteers strengthened the regular army at a critical moment of the war. Also the society of the Lodz region has shown that in the most important moments for Poland it is capable of making great sacrifices in the name of defending the independence of the country.

Key words: General District of the Polish Army No. IV Lodz; Polish-Bolshevik war; history of Lodz; Volunteer Army. 